\title{
Theory about the object of a bribe: analysis of the Law
}

\author{
$1 \mathrm{PhD}$, Associate Professor, Altai State University, Barnaul, Russian Federation. \\ E-mail: kovalenko1288@mail.ru (iD https://orcid.org/0000-0001-6017-8933 \\ 2 Altai State University, Barnaul, Russian Federation. \\ E-mail: v.deminova1@inbox.ru (iD https://orcid.org/0000-0002-1239-0953 \\ 3 Altai State University, Barnaul, Russian Federation. \\ E-mail: v.deminova1@inbox.ru (iD https://orcid.org/0000-0003-1990-5822
}

\author{
Kseniya E. Kovalenko ${ }^{1}$ \\ Viktoriya Yu. Gorovaya ${ }^{2}$ \\ Svyatoslav A. Gorovoy ${ }^{3}$
}

\begin{abstract}
This article analyzes the subject of the offense of receiving a bribe. The possibility of recognition as the subject of receiving a bribe of sexual services, counterfeit banknotes, narcotic drugs, psychotropic substances is being considered. Attention is drawn to the fact that according to statistical information to date, most facts of receiving the subject of a bribe remain outside the scope of the offense under Art. 290 of the Criminal Code of the Russian Federation, due to the fact that they do not reach the minimum limit.

Keywords: Receipt of a bribe. Subject of a bribe. Qualification. Official. Law.
\end{abstract}

\section{INTRODUCTION}

Despite the fact that the crime in question has long been known to the criminal law and is very common in practice, a number of issues of its qualification are still controversial. So, the question of the subject of receiving a bribe is debatable.

From the point of view of the doctrine of criminal law, the subject of a crime is that which is directly affected by the person committing the crime. It should be considered as a sign of such an element of corpus delicti as the object; the subject of the crime should be included in the structure of public relations, which is the direct object of the crime.

Given the debatability of the issue of the object of receiving a bribe in the scientific field, there is no single approach to determining the subject of this crime.

Disposition h. 1 Article 290 "Receiving a bribe" of the Criminal Code of the Russian Federation allows the following to be attributed to the subject of a bribe: 1) money; 2) se- curities; 3) other property; 4) property services; 5) property rights. It is advisable to examine these subjects in more detail.

\section{DEVELOPMENT}

In accordance with the provisions of Article 140 of the Civil Code of the Russian Federation, money must be understood as both Russian and foreign currency in circulation at the time the crime was committed. In accordance with the provisions of the Federal Law "On Currency Regulation and Currency Control" dated December 10, 2003 No. 173-FL, the currency of the Russian Federation is:

a) banknotes and Bank of Russia coins in circulation as legal tender in cash on the territory of the Russian Federation, as well as withdrawn or withdrawn from circulation, but subject to exchange;

b) funds in bank accounts and in bank deposits.

Foreign currency represents banknotes in the form of banknotes, treasury bills, coins 
that are in circulation and are legal tender in the territory of the corresponding foreign state (group of foreign states), as well as these banknotes withdrawn or withdrawn from circulation, but subject to exchange; funds in bank accounts and in bank deposits in monetary units of foreign states and international monetary or settlement units.

Money is one of the objects of civil rights. From the standpoint of economic theory, money is the equivalent of the value of something. Money as a subject of a bribe must be understood in this sense. It does not matter whether it is a Russian currency (bank tickets or a metal coin) or a currency of foreign states. The main thing is that this currency is in economic circulation, otherwise we are talking about other property.

It seems problematic to receive fake money as a bribe. Scientific publications on this subject often indicate that counterfeit banknotes or coins will not be legal tender and cannot be in cash. They are deprived of all the economic properties inherent in real money, and therefore money in the legal sense of the word is not. For this reason, it is stated that fake banknotes and coins cannot be recognized as the subject of a bribe. Moreover, according to R.D. Sharapova, it is impossible to give the counterfeit banknotes the grade required in criminal cases of bribery and mandatory for calculating the size of a bribe.

Nevertheless, we believe that counterfeit banknotes that do not have the property of turnover and are prohibited for use by the current Russian legislation retain their proprietary nature and, accordingly, should belong to the category of things withdrawn from civil circulation. This approach allows us to attribute fake banknotes to other property, which is indicated as the subject of a crime in Art. 290 of the Criminal Code. This provision follows from the fact that a bribe may be things whose circulation is limited, as well as things that are withdrawn from circulation, including those obtained by criminal means.

It seems that in this aspect there will be no contradiction with the provision of Clause 9 of the Resolution of the Plenum of the Supreme Court of the Russian Federation of July 9, 2013 No. 24 "On judicial practice in cases of bribery and other corruption crimes": "Transferred as a bribe or commercial item bribery of property, property services rendered or property rights granted should receive a monetary value based on the evidence submitted by the parties, including, if necessary, taking into account the expert's opinion. "On the other hand, one cannot but pay attention to the statement of V. V. Hilyuta, indicating that this paragraph of clarification deals with legitimate bribery items (property, property services rendered or property rights granted), and nothing is said about the valuation of objects excluded or restricted in civil circulation, that is, about illegitimate material benefits.

\section{RESULT.}

It is important, when the subject of receiving a bribe is illegal property values, to remember that the fact of receiving a bribe, that is, receiving wealth having a property character, is criminal here. It seems that this issue is most accurately disclosed in paragraph 5 of the resolution of the Plenum of the Supreme Court of the Republic of Belarus dated June 26, 2003 No. 6 "On judicial practice in cases of bribery", which states that material values (namely money, securities, things, etc.) or of a proprietary nature of the benefit, regardless of their value, provided to an official solely in connection with his official position, may be the subject of a bribe. In order to streamline judicial practice, it would be advisable to adopt this experience at the level of clarification in the resolution of the Plenum of the Supreme Court of the Russian Federation. 
Analyzing securities as a subject of a bribe, it should be noted that they are also one of the objects of civil rights. The definition of a security is given in paragraph 1 of Art. 142 of the Civil Code of the Russian Federation: "Securities are documents that meet the requirements established by law and certifying obligations and other rights, the exercise or transfer of which is possible only upon presentation of such documents (documentary securities). Securities also recognize obligations and other rights that are enshrined in a decision on the issue or other act of a person who issued securities in accordance with the requirements of the law, the exercise and transfer of which is possible only in compliance with the rules for accounting for these rights in accordance with Article 149 of this Code (non-documentary securities)". An open list of securities is provided in paragraph 2 of Article 142 of the Civil Code of the Russian Federation. They are stocks, promissory notes, mortgages, investment shares of a mutual investment fund, a bill of lading, a bond, a check and other securities designated as such in the law or recognized as such in the manner prescribed by law.

A systematic interpretation of the Criminal Code of the Russian Federation leads us to the conclusion that in Art. 290 of the Criminal Code of the Russian Federation, securities are understood to mean only documentary securities.

The generalized concept of property is not given in civil law. If you follow the provisions of Art. 128 of the Civil Code of the Russian Federation, then the concept of "property" includes things, including cash and documentary securities, other property, including cashless funds, uncertificated securities, property rights. The Civil Code of the Russian Federation follows the path of a simple listing of common types of property, while leaving this list open. It should be noted that the concept of "property" includes not only securities, money, but also property rights, which are separately named in the Criminal Code of the Russian Federation. Thus, the legislator uses the same terms with different meanings in different branches of legislation, which is a defect in the current legislation. The accuracy and ratio of definitions, the uniformity of values when using them is the key to law enforcement.

Often, the doctrine of criminal law raises the question: will a thing taken out of civilian traffic, or a thing partially limited in it, be the subject of a bribe? In particular, this category includes donor organs, weapons, narcotic drugs and psychotropic substances, explosives and explosive devices.

The potential possibility of not recognizing such things as a bribe is associated with the lack of their official value. At the same time, it is obvious that the removal or restriction of something from civil circulation does not affect the physical properties of a thing. Such a thing remains an object of the material world with a certain value. The draft resolution of the Plenum of the Supreme Court of the Russian Federation "On judicial practice in cases of bribery, commercial bribery and other corruption crimes" contained a direct proposal to evaluate such items "taking into account prices formed in the market of illegal services". This approach seems to us quite true.

Services are an independent object of civil rights. In Art. 128 of the Civil Code of the Russian Federation, they are used in conjunction with the results of the work. Representatives of the science of civil law offer to distinguish these objects as independent. The decision of the Plenum of the Supreme Court of the Russian Federation dated July 9, 2013 No. 24 "On judicial practice in cases of bribery and other corruption crimes" states that "by illegal provision of property-related services, courts should understand the provision of any property benefits to an official as a bribe , including exemption from property obliga- 
tions (for example, repair of an apartment, free provision of tourist permits, provision of a loan with a low interest rate for using it, a builder the property of a summer residence, the transfer of property, in particular motor transport, for its temporary use, fulfillment of obligations to other persons, forgiveness of debt) "(paragraph 9). That is, the highest court determines property services in the form of property benefits, in line with the terminology of civil law, referring to them and the results of work and services.

Earlier in the wording of Art. 290 of the Criminal Code of the Russian Federation, property benefits as a bribe were used together with property services. According to the remarks of individual authors, such a correction "the legislator tried to make more specific" non-monetary "forms of bribery". In our opinion, concretization was not entirely successful, if only because the issue of property or non-property of some services remained a problem.

Earlier it was said that the Criminal Code uses the concepts of "property services" and "property rights". This means that the legislator excluded non-property services and nonproperty rights from the subject of the bribe.

Although in the doctrine, not everyone agrees with this. For example, E. V. Krasnopeeva suggests that it would be appropriate "to supplement Part 1 of Art. 290 of the Criminal Code after the words "... or property benefits" in brackets with the word "nonproperty" with respect to determining the nature of the benefits derived by an official for committing bribery".

The category of non-property law has long been known to civil law (for example, intangible goods, personal non-property rights), and as for non-property services, the Civil Code does not mention this in any of the norms. Moreover, a simple search on the Internet shows that the phrase is used very rarely, and, as a rule, when talking about a bribe. It should agree with the opinion of P.S. Yani, who noted that due to the fact that civil law does not know the term "non-property services", in the framework of law enforcement this term can be understood more broadly - that is, as having independent content for the purposes of criminal law.

Most often, in studies, when mentioning the non-property of services, they say that it is impossible to give such a monetary value, although, for example, I. S. Alikhadzhieva, coauthor of the article-by-article Commentary on the Federal Law "On Combating Corruption", writes that "every service, even nonproperty, has a corresponding cost".

First of all, in practical terms, among nonproperty services are called sexual services, as well as promotion. In addition, nonproprietary services include situations when an official seeks career advancement in favor of his relative or close person for his counter promotion of the person who has applied to him. Also, non-property services also often include the giving of an oral or printed favorable review, a certificate of honor, promotion or connivance in the service, salary increase, positive characteristics, recommendations, refusal to disclose compromising information.

The possibility of recognition as a bribe of sexual services is of particular scientific interest. In the scientific literature there are four points of view on this issue:

1) it is always a bribe, since there is a black market for such services and they are very easy to evaluate;

2) they can never be a bribe, as they are closely related to the person, in fact they are non-property services that the Criminal Code does not relate to the subject of the bribe;

3) they are not a bribe, since the paid provision of sexual services is illegal: "the resolution of the Plenum refers only to legal services"; "Such services "should not be paid while prostitution is prohibited by law. Understanding as a property benefit of such 
"services" contradicts the foundations of law and order and morality, and payment of such does not give them a property nature ";

4) in certain cases it is a bribe, in others it is not. It all depends on the fundamental valuation of these services.

The first point of view presented is rather vulnerable. So, the question of what price this or that person evaluates his own sexual services will cause outrage among the majority. Moreover, it is difficult to imagine such an assessment of sexual services by an expert.

The second position is also not without flaws. The attribution of certain services to property or non-property is very controversial. In many cases, when providing sexual services, this "property" can be found and the services themselves evaluated.

The analysis of the third approach shows that legality as a criterion for assigning something to the subject of a bribe does not meet modern realities. Following this approach, it would be necessary to exclude narcotic drugs, psychotropic substances, firearms and other things taken from civilian circulation from the subject of a bribe. During the discussion of the draft resolution of the Plenum of the Supreme Court of the Russian Federation "On judicial practice in cases of bribery and other corruption crimes", it was noted that "services of an illegitimate nature may be subject to a bribe, the cost of which can be established taking into account prices formed on the market of illegal services.

For accurate and correct qualification of actions in similar situations (non-property rights, non-property services), it is important to proceed from the subjective representations of the official about the non-property or property of this service in each case, taken separately. Accordingly, if the receipt of a non-property service by an official is perceived only as an opportunity not to pay money for it, then this service is the subject of a bribe. Otherwise, no. The same goes for the bribe giver. The aforesaid is confirmed by the understanding of receiving a bribe as a mercenary crime, which in turn implies precisely the desire to obtain property benefits from a bribe.

Finally, property rights are called the subject of a bribe in the Criminal Code of the Russian Federation. In accordance with paragraph 9 of the above resolution of the Plenum of the Supreme Court of the Russian Federation "property rights include both the right to property and other rights that have a monetary value, for example, the exclusive right to the results of intellectual activity and equivalent means of individualization (Article 1225) Civil Code of the Russian Federation). "

L. I. Farberova notes that "as the subject of a crime under Art. 290 of the Criminal Code, property law does not imply a legally registered right of ownership of property, because in this case the property itself should be considered as an object, and not the right to it, on the other hand, property law includes property rights that cannot be attributed to the "right on property". It seems that from the property-value relations regulated by the rules of civil law, a certain set of competences of the subjects proceeds. Taking into account the classification of property relations into property and liability, we note that property law, therefore, acts both as a property right (which ensures the satisfaction of a person's interests by directly affecting a thing that is within the scope of his economic dominance) and as a liability law (ensuring the satisfaction of the interests of the authorized person by virtue of certain actions of the obligated person to provide appropriate goods).

Thus, property law as a subject of a bribe is:

1) the obligation of the creditor to transfer property, perform work or provide property services;

2) other property rights, with the exception of the right of ownership, which materializes 
in the form of money, securities and other property;

3) otherwise legally formalized opportunity to acquire the right of ownership of things (for example, the rights of the heir by will);

4) the exclusive right to the results of intellectual activity and equivalent means of individualization.

Studying the question of the size in which these items can be obtained, we note that in accordance with Note 1 to Art. 290 of the Criminal Code of the Russian Federation a significant amount for the purposes of Article 290, 291 and 291.1 of the Criminal Code of the Russian Federation is the amount of money, the value of securities, other property, property services, other property rights in excess of 25 thousand rubles. In turn, the legislator recognizes a large amount of money, the value of securities, other property, property services, other property rights in excess of 150 thousand rubles, and especially large - in excess of 1 million rubles.

\section{CONCLUSION}

According to statistical information to date, most of the facts of receiving the subject of a bribe remain outside the scope of the offense under Art. 290 of the Criminal Code, due to the fact that they do not reach the minimum limit. So, for the period 2014-2017. more than $70 \%$ of sentences for bribes were made due to amounts of up to 10 thousand rubles. During this period, 274 people were convicted of receiving intangible bribes; for receiving a bribe of less than 1000 rubles. - 6773 people; up to the amount of 50 thousand rubles. - 2985 people; up to the amount of 150 thousand rubles. - 982 people; up to the amount of 1 million rubles. - 874 people; in the amount of over 1 million rubles. - 309 people.

In connection with this trend, Federal Law of July 3, 2016 No. 324-FL “On Amendments to the Criminal Code of the Russian Federation and the Code of Criminal Procedure of the Russian Federation" introduced Art. 291.2 of the Criminal Code (petty bribery). The objective side of petty bribery is to receive a bribe by an official and (or) to give a bribe to an official in person or through an intermediary in an amount not exceeding 10 thousand rubles.

Thus, according to the disposition of Part 1 of Art. 290 of the Criminal Code of the Russian Federation, the subject of a bribe may be money, securities, other property, property rights, property services. The basic structure of receiving a bribe (part 1 of article 290 of the Criminal Code of the Russian Federation) implies receiving the subject of a bribe in the amount of over 10 thousand rubles

Concerning the discussion subjects of taking a bribe, the following conclusions are formulated.

Counterfeit banknotes, in spite of the fact that they do not have the property of turnover and a ban on the use of legislation, retain the proprietary nature and belong to the category of things withdrawn from civil circulation. They should be attributed to other property as an object of receiving a bribe.

It is acceptable to evaluate narcotic drugs and psychotropic substances, explosives and explosive devices, donor organs and other items withdrawn from civilian traffic, taking into account the prices formed in the market of illegal services.

When recognizing as a subject of receiving a bribe non-property services, including services of a sexual nature, it is necessary to proceed from the subjective representations of the official about the non-property or property of the service in a particular case. If the official perceives the receipt of the service as an opportunity not to pay for it, such a service is the subject of the crime in question. 


\section{REFERENCES}

BRAZHNIK, F. S. Some topical issues of qualification of receiving a bribe. Criminal law. 2000, 1.

Civil law: textbook: Part 2 / ed. A.P. Sergeeva, Yu.K. Tolstoy. Moscow, 2005.

Commentary on the Federal Law "On Combating Corruption" (post.). Free electron. Library. Access mode: http://modernlib.ru Zagl. from the screen. (Date of treatment: 09/10/2019).

DINEKA, V. I. Official crimes under the criminal law of Russia. Stavropol, 1999.

FARBEROVA, L. I. Illegal granting of property right as a subject of bribery. Jurisprudence and law enforcement practice. 2014, 1 (27).

FARBEROVA, L. I. Receiving a bribe in the form of money: a criminal law characteristic and qualification issues. Bulletin of the Tyumen Institute for Advanced Studies of the Ministry of Internal Affairs of Russia. 2013, 1.

HILYUTA, V. V. Counterfeit money as a subject of bribery. Legality. 2017, 5 .

IVANOV, N. To the discussion of clarifications of the Plenum of the Supreme Court on the qualifications of bribery. Criminal law. 2013, 5.

KACHALOV, V. V. The terminology of criminology: problems and development prospects. Bulletin of the Moscow University of the Ministry of Internal Affairs of Russia. 2014, 14.

KLEPITSKY, I. A. Receiving a bribe in the criminal law of Russia. Commentary on legislation. Moscow, 2001.

KOVALENKO, K. E., ROZENTSVAİG, A. I., GUBAREVA, A.V. International terrorism and international cyberterrorism. Quidinvestigacion ciencia y tecnologia. 2018, 2 (SI).
KRASNOPEEVA, E. V. The subject of a bribe and the qualification of the deed. Legality. 2001, No. 8.

SHARAPOV, R. D. Money, securities and other property as a subject of a bribe: criminal law characteristics and qualification issues. Academic Bulletin. 2003, 1.

SITKOVETS, O. N. Responsibility for receiving and giving a bribe. Russian investigator. 2005, 1.

Statistical and analytical materials on the status of work to identify corruption crimes, investigations and prosecutorial supervision of criminal procedural activities of law enforcement agencies in the fight against corruption // Official website of the Prosecutor General of the Russian Federation [Electronic resource]. Access mode: //genproc.gov.ru/anticor/do ks/document-81540/ - Zagl. from the screen. (accessed September 25, 2019).

VDOVIN, R. A., ROZENTSVAIG, A. I., KOVALENKO, K. E., KOVALENKO, N. E. Defects of terminology in law and technique. Religacion-revista de ciencias sociales y humanidades. 2019, 4(18) SI.

VOLZHENKIN, B. V. Official crimes. Moscow, 2000.

YANI, P.S. Qualification issues of bribery. Legality. 2013, 3.

ZHILLKIN, M. G. Novels of criminal liability for bribery. Actual problems of combating corruption in modern conditions: materials interagency. Scientific and practical conf. (March 21, 2012). Ruza, 2012.

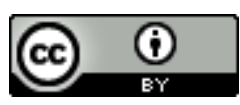

License information: This is an openaccess article distributed under the terms of the Creative Commons Attribution License, which permits unrestricted use, distribution, and reproduction in any medium, provided the original work is properly cited.

Article received on November 10, 2019.

Evaluated November 15, 2019.

Accepted on November 15, 2019.

Published on November 21, 2019. 
How cite this article (ABNT):

KOVALENKO, Kseniya E.; GOROVAYA, Viktoriya Yu.; GOROVOY, Svyatoslav A. Theory about the object of a bribe: analysis of the Law. Estação Científica (UNIFAP), Macapá, v. 9, n. 2, p. 71-78, apr./jun. 2019. 